\title{
Entrapment Formulation for env-Tm Gene Based on Chitosan Low Molecular Weight as a Jembrana Disease Virus Vaccine Candidate
}

\author{
Indra Lesmana Rahayu ${ }^{1, *}$ and Asmarani Kusumawati ${ }^{1,2^{*}}$ \\ ${ }^{1}$ Department of Biotechnology, Postgraduate School, Universitas Gadjah Mada, Jl. Teknika Utara, \\ Sleman, Yogyakarta 55281, Indonesia \\ ${ }^{2}$ Department of Reproduction and Obstetrics, Faculty of Veterinary Medicine, Universitas Gadjah \\ Mada, Jl. Fauna Karangmalang No.2, Yogyakarta 55281, Indonesia
}

\begin{abstract}
Jembrana disease (JD) caused by Jembrana Disease Virus (JDV) becomes an obstacle in Bali cattle (Bos javanicus). The development of JD vaccines has a critical meaning to prevent losses in the B. javanicus in Indonesia and is one of the models in the development of the Human Immunodeficiency Virus (HIV) vaccine. The development of vaccines for JDV has carried out DNA vaccines that are expected to provide better immunological effects. This study aimed to determine the low molecular weight chitosan (LC) entrapment towards pEGFP-C1-env$\mathrm{Tm}$ in the formation of Chitosan Nanoparticles Low/pEGFP-C1-env-Tm complex. The env-Tm gene was inserted in pEGFP-C1 into the pEGFP$\mathrm{C} 1 / e n v-T m$ construct transformed on the E. coli $\mathrm{DH} 5 \alpha$ host. The construct was formulated into LC/pEGFP-C1/env-Tm complex with a low molecular weight chitosan concentration of $0.06 \%$ and the ratio of pEGFP-C1/envTm: LC (wt/wt) was 1:0.5-1:3. The complexes were then analyzed by gel retardation assay agarose $1 \%$. The results of this study indicated that the best entrapment results of low molecular weight chitosan to pEGFPC1/env-Tm was in the mass ratio of pEGFP-C1/env-Tm: LC was 1:2. The best formulation entrapment for $e n v-T m$ by low molecular weight chitosan $0.06 \%$ is in the rate $1: 2$.
\end{abstract}

Keywords: Env-tm gene, jembrana disease virus, low molecular

\section{Introduction}

The obstacle faced by Bali cattle is Jembrana Disease (JD), which is caused by bovine lentivirus, a member of the family retroviridae, subfamily lentiviridae. This disease can affect the fertility of Bali cattle, thereby reducing the production of Bali cattle, which can affect economic conditions in Indonesia [1-5]. Thus, prevention is needed to prevent the disease spread. DNA vaccines are proven effective in primates, stable in storage, easy to produce, safe (non-replicative), express only target antigens, cannot be returned pathogenic, and able to induce cellular and humoral immunity [6-8].

The delivery of pDNA using nonviral vectors results in gene expression, which encourages the development of new delivery systems that can protect pDNA, as well as localize its delivery, such as chitosan. Chitosan can protect therapeutic agents from nuclear

* Corresponding author : asmaranikusumawati2018@gmail.com 
degradation both in vitro and in vivo, and can be formulated for the delivery of pDNA [9]. Therefore, this research was carried out on the use of low molecular weight chitosan as a protective molecule as well as carrying the target gene to cells

\section{Materials and methods}

\subsection{Material}

The gene encoding transmembrane portion of envelope protein from JDV, which had previously been isolated from infected cattle and cloned into the plasmid enhanced green fluorescent protein $\mathrm{C}$ terminus (pEGFP-C1) vector (Clontech, USA) to construct pEGFPenv-Tm JDV. Chitosan of low molecular weight (50 $000 \mathrm{Da}$ to $190000 \mathrm{Da}$, based on viscosity: $20 \mathrm{cP}$ to $300 \mathrm{cP}$ ) was purchased from Sigma (Singapore).

\subsection{Methods}

\subsubsection{LC/pEGFP-C1-env-Tm complex preparation}

Low molecular weight of chitosan as much as $1 \mathrm{~g}$ was dissolved in $100 \mathrm{~mL}$ of $1 \%(\mathrm{v} / \mathrm{v})$ acetic acid. The low molecular weight chitosan solution was then sterilized using a $0.2 \mu \mathrm{m}$ syringe filter (Merck, Germany). The solution was then diluted using nuclease-free water (NFW) (TransGen Biotech, China) to a concentration of $0.06 \%$, and was used as a stock to make LC/pEGFP-C1/env-Tm complex. The preparation of the LC/pEGFP-C1/env-Tm complex was performed with the complex coacervation method with modifications [10]. A total amount of $1 \mu \mathrm{g}$ plasmid and different amounts of low molecular weight chitosan were heated separately at $50{ }^{\circ} \mathrm{C}$ for $10 \mathrm{~min}$. Then, plasmid construct and low molecular weight chitosan solution were mixed with a volume ratio by vortexing at $2500 \mathrm{rpm}$ ( $1 \mathrm{rpm}$ $=1 / 60 \mathrm{~Hz}$ ) for $30 \mathrm{~s}$. The mass ratios of DNA and chitosan used were 1:0.5 to 1:3 (wt/wt).

\subsubsection{Gel retardation essay analysis}

The formation of LC/pEGFP-C1/env-Tm complex was examined using a gel retardation assay in agarose gel electrophoresis. The LC/pEGFP-C1/env-Tm complexes were electrophoresed on a $1 \%$ agarose gel with Gel Stain (TransGen Biotech, China). Unbound pEGFP-C1-env-Tm and low molecular weight chitosan solution were used as negative controls.

\section{Results}

\subsection{LC/pEGFP-C1/env-Tm complex}

The formation of LC/pEGFP-C1/env-Tm complex was observed with a gel retardation assay on agarose gel $1 \%$. Several different DNA mass ratios and low molecular weight chitosan were used, and only in the 1:2 and 1:3 ratio were complexes formed, seen with entrapped LC/pEGFP-C1/env-Tm complexes in the well. Low molecular weight chitosan solution as a negative control cannot bind DNA, and it can show the absence of the band. Free plasmid DNA migrates into two DNA bands that show two different plasmid conformations. The bands of unbound pEGFP-C1/env-Tm could still be detected with a ratio of 1:0.5 and 1:1 but not detected in a higher LC/pEGFP-C1/env-Tm ratio complex 
(Figure 1). The results in this study indicate that the best entrapment results of low molecular weight chitosan to pEGFP-C1/env-Tm is in the mass ratio of pEGFP-C1/env-Tm: LC is $1: 2$ that entrapped the entire amount of plasmid DNA. This was the same as research conducted by Ishak (2019) regarding the use of medium molecular weight chitosan with pDNA $(e n v-T m)$ with a chitosan concentration of $0.02 \%$, which chitosan/pDNA complex is entrapped in well at a ratio of 1: 2 [11].

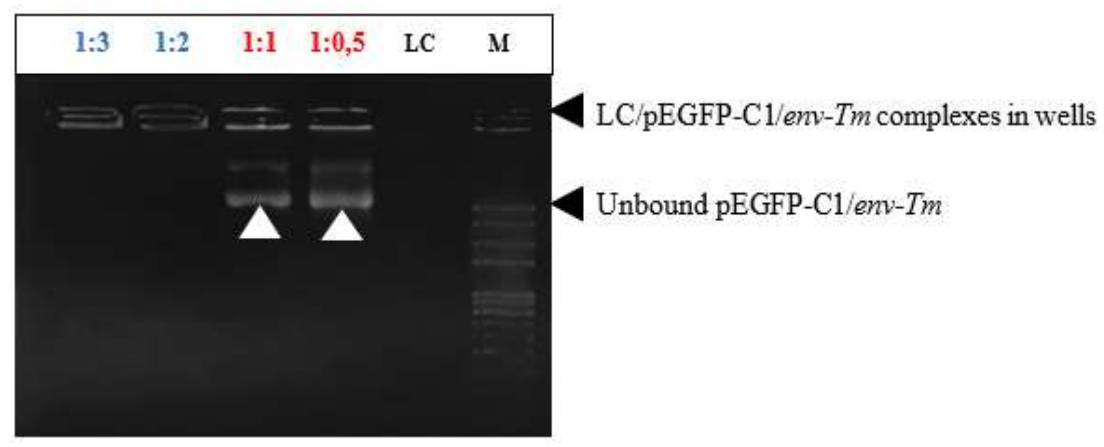

Low Molecular Weight Chitosan $0.06 \%$

Fig. 1. Agarose gel retardation assay of LC/pEGFP/env-Tm complexes. $(\mathrm{M})=$ Marker, $(\mathrm{LC})=$ Low Molecular Weight Chitosan

\section{Discussion}

Chitosan complex is widely used in the pharmaceutical world as a transport agent capable of releasing controlled molecules such as DNA, vaccines, peptides, or antibiotics [12]. This research focuses on the success of entrapped LC/pEGFP-C1/env-Tm complexes in well with $0.06 \%$ chitosan concentration, $1: 2$ ratio (wt/wt).

Particle formation occurs at the N/P ratio, which is the ratio between nitrogen $(\mathrm{N})$ chitosan per phosphate (P) DNA, which is essential for determining the charge on the surface of the particle. Chitosan has one primary amino group in repeated glucosidic residues that gives a positive charge. Chitosan has a unique cationic character. That is because chitosan has a major amino group that is responsible for providing strong electrostatic interactions with negative charges on DNA $[13,14]$.

The important thing in making a vaccine is that the complexes formed between the delivery agent and pDNA can enter the cell and express the target gene carried. Various factors that affect transfection efficiency are molecular weight (MW), degree of deacetylation (DD), chitosan-DNA molar ratio, DNA complex charge ratio (N: P ratio) and $\mathrm{pH}$, and particle size. High load density, making chitosan with high MW, can't release the charge to the cytoplasm, but conversely, chitosan with low MW is much better at delivering genes. Additionally, in the formulation of making DNA vaccines, particle size and shape also depends on the conditions involved in the formulation process, including salt concentration, molecular weight complex, and chitosan concentration, and the mixing process $[13,15,16]$.

\section{Conclusion}

The best formulation entrapment for $e n v-T m$ by low molecular weight chitosan $0.06 \%$ is in the ratio $1: 2$. 


\section{References}

1. I.W.M. Tenaya. Buletin Veteriner Udayana, 8,2:187-202(2016).[in Bahasa Indonesia].

https://www.google.co.id/url? sa $=$ t\&rct $=\mathrm{j} \& \mathrm{q}=\&$ esrc $=\mathrm{s} \&$ source $=$ web\&cd $=\& v e d=2 \mathrm{ah}$ UKEwiQ6o7Q68rrAhWL7HMBHaC_BzIQFjAAegQIARAB\&url=https\%3A\%2F\% 2Fojs.unud.ac.id $\% 2$ Findex.php $\% 2$ Fbuletinvet $\% 2$ Farticle $\% 2$ Fdownload $\% 2 F 23318 \%$ 2F15323\%2F\&usg=AOvVaw1TSEHp-GG9ngaA-NpunpBQ

2. A. Kusumawati, I.A. Wulandari, A. Ratnawati, S. Hartati, T. Untari. Jurnal Veteriner, 16,4:569-575(2015).[in Bahasa Indonesia]

3. https://ojs.unud.ac.id/index.php/jvet/article/view/17340/11393

4. F. Lebre, G. Borchard, H. Faneca, M.C.P.d. Lima, O. Borges. Mol. Pharm., 13:472-82(2016). https://pubs.acs.org/doi/abs/10.1021/acs.molpharmaceut.5b00707

5. J.A. Williams. Vaccines, 1,3:225-249(2013). https://www.ncbi.nlm.nih.gov/pmc/articles/PMC4494225/

6. I.W.M. Tenaya. Buletin Veteriner Udayana, 8,2:187-202(2016).[in Bahasa Indonesia]

https://www.google.co.id/url?sa $=\mathrm{t} \& \mathrm{rct}=\mathrm{j} \& \mathrm{q}=\&$ esrc $=\mathrm{s} \&$ source $=$ web\&cd $=\& v e d=2 \mathrm{ah}$ UKEwiQ6o7Q68rrAhWL7HMBHaC_BzIQFjAAegQIARAB\&url=https $\% 3 \mathrm{~A} \% 2 \mathrm{~F} \%$ 2Fojs.unud.ac.id\%2Findex.php $\% 2$ Fbuletinvet $\% 2$ Farticle $\% 2$ Fdownload $\% 2 F 23318 \%$ 2F15323\%2F\&usg=AOvVaw1TSEHp-GG9ngaA-NpunpBQ

7. G. Widera, M. Austin, D. Rabussay, C. Ulmer, S.W. Barnett, M. Chen, et al. J. Immunol., 164,9:4635-4640(2018). https://pubmed.ncbi.nlm.nih.gov/10779767/

8. K. Zhao, Y. Zhang, X. Zhang, W. Li, C. Shi, C. Guo, et al. Int. J. Nanomedicine, 9:389-402(2014). https://www.ncbi.nlm.nih.gov/pmc/articles/PMC3890423/

9. A.O. Abbas, M.D. Donovan, A.K. Salem. J. Pharm. Sci., 97,7:2448-24641(2008). https://pubmed.ncbi.nlm.nih.gov/17918737/

10. K. Zhao, Y. Zhang, X. Zhang, C. Shi, X. Wang, X. Wang, et al. Int. J. Nanomedicine, 9:4609-4619(2014)

https://www.ncbi.nlm.nih.gov/pmc/articles/PMC4207079/

11. R. Martien, B. Loretz, M. Thaler, S. Majzoob, A. Bernkop-Schnurch. J. Biomed. Mater. Res. A. 82,1:1-9(2007).

https://www.researchgate.net/publication/6539973_Chitosanthioglycolic_acid_conjugate_An_alternative_carrier_for_oral_nonviral_gene_delive ry

12. J. Ishak, L. Unsunnidhal, R. Martien, A. Kusumawati. J. Vet. Res., 63:7-16(2019). https://www.ncbi.nlm.nih.gov/pmc/articles/PMC6458558/

13. R. Martien, A. Adhyatmika, I.D.K. Irianto, V. Farida, D.P. Sari. J Pharm, 8,1:133139(2012).[in Bahasa Indonesia] https://jurnal.ugm.ac.id/majalahfarmaseutik/article/view/24067

14. L. Hu, Y. Suna, Y. Wu. Nanoscale, 5:3103-3111(2013). https://pubs.rsc.org/en/content/articlelanding/2013/nr/c3nr00338h\#!divAbstract

15. J. Nilsen-Nygaard, S.P. Strand, K.M. Vårum, K.I. Draget, C.T. Nordgård. Polymers, 7,3:552-579(2015). https://www.mdpi.com/2073-4360/7/3/552

16. T. Kiang, J. Wen, H.W. Lim, K.W. Leong. Biomaterials, 25,22:5293-5301(2004). https://pubmed.ncbi.nlm.nih.gov/15110480/

17. T. Delair. Eur. J. Pharm. Biopharm., 78,1:10-18(2011). https://europepmc.org/article/med/21138767 